\begin{tabular}{ll}
\hline \hline MINING AND METALLURGY INSTITUTE BOR & ISSN: 2334-8836 \\
& UDK: 622 \\
\hline \hline
\end{tabular}

\title{
REVIEW OF CONTEMPORARY WORLD STUDIES ON CHARACTERISTICS OF FLY ASH AS A SECONDARY MINERAL RESOURCE: PART $1^{* *}$
}

\begin{abstract}
Nowadays, there is an increasing tendency that fly ash from thermal power plants is not only considered as a waste material that is a burden, but as an important secondary raw material that can be useful applied in various branches of economy. Therefore, this paper gives a description of the main characteristics of fly ash, as well as its chemical, mineralogical composition and morphological composition. Depending on those factors, the possibility of fly ash usage depends. In addition, the paper presents some standard norms prescribed by the national and international standards, which relate to the quality of fly ash in terms of its chemical composition.

Keywords: fly ash, secondary mineral raw materials
\end{abstract}

\section{INTRODUCTION}

Fly ash is a heterogeneous mixture of particles of different physical, chemical, mineralogical, and morphological characteristics formed by coal combustion in power plants and characterized by a certain quality of burnt coal, combustion technology and combustion conditions. In literature, there are several proposals for systematization and classification of fly ash. According to the International System of Classification, a division of fly ashes was done on the basis of content of $\mathrm{SiO}_{2}$ and $\mathrm{Al}_{2} \mathrm{O}_{3}$, in four main groups [1]. These are:

- Aluminosilicate (type I), in which the mass ratio of $\mathrm{SiO}_{2} / \mathrm{Al}_{2} \mathrm{O}_{3}>2$, $\mathrm{CaO}$ content less than $15 \%$, whereas $\mathrm{SO}_{3}$ content is not defined.
- Silica-aluminate (type II), in which the ration $\mathrm{SiO}_{2} / \mathrm{Al}_{2} \mathrm{O}_{3}<2, \mathrm{CaO}$ content less than $15 \%$, and $\mathrm{SO}_{3}$ content is less than $3 \%$.

- Sulfate-alkaline (type III), which contains more than $15 \%$ of $\mathrm{CaO}$ and more than $3 \%$ of $\mathrm{SO}_{3}$, and the mass ratio of $\mathrm{SiO}_{2}$ and $\mathrm{Al}_{2} \mathrm{O}_{3}$ is not defined.

- Calcitic (type IV) with high content of $\mathrm{CaO}(>15 \%)$ and low content of sulfate $(<3 \%)$, whereas the ratio of $\mathrm{SiO}_{2} / \mathrm{Al}_{2} \mathrm{O}_{3}$ is also not defined.

\section{FORMATION OF FLY ASH}

Fly ash presents the finest fraction, left over after coal combustion in power plants

\footnotetext{
* Mining and Metallurgy Institute Bor, Zeleni bulevar 35, Bor

** This work is the result of the Project No. 34006: Mechanochemical Treatment of Low Quality Mineral Resources, and Project No. 37001: Impact of Mining Waste from RTB to Pollution of Waterways with a Proposal of Measures and Actions to Reduce Harmful Effects on the Environment, funded by the Ministry of Education, Science and Technological Development of the Republic of Serbia.
} 
(Figure 1). It is separated on electrofilters, and its grain size is usually in the range $0 \div 1$ $\mathrm{mm}$. Characteristics of fly ash are primarily caused by phase composition of inorganic component of coal and its transformations during combustion. Inorganic component of coal consists of impurities that are highly dispersed in coal mass, i.e. a pure coal sub stance of organic structure [2]. These components are partially chemically bonded to the coal mass.

Up to $95 \%$ of impurities are three main groups of minerals - aluminosilicate (i.e. clay minerals), sulfide and carbonate minerals. Table 1 shows the common minerals, found in coal [1].

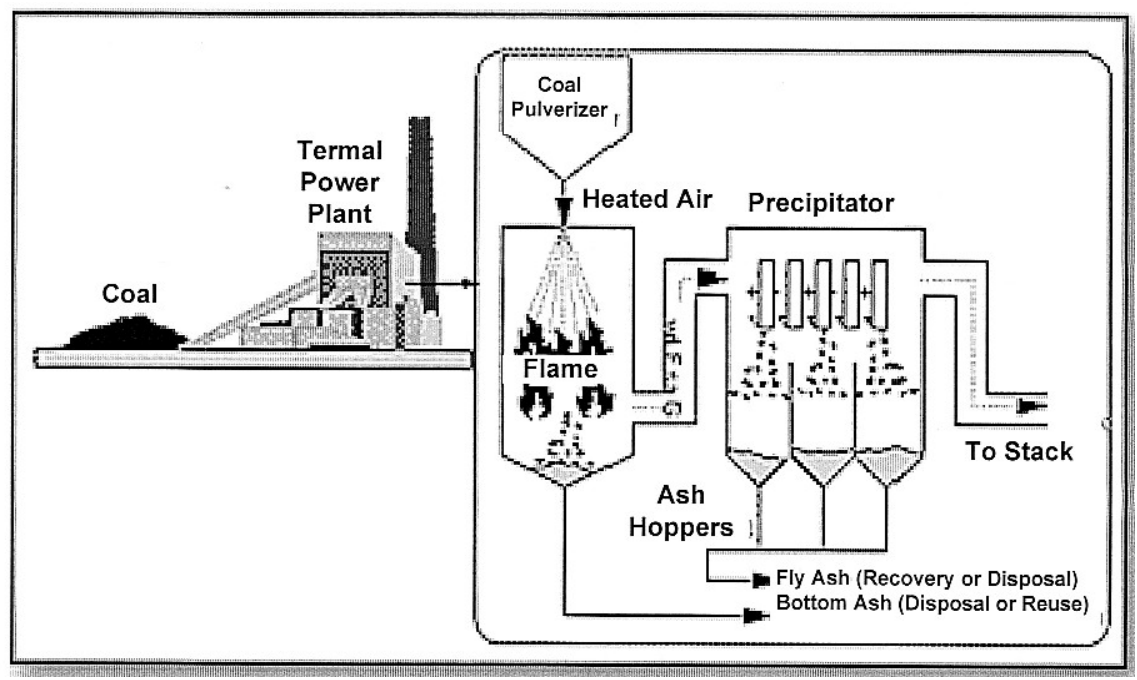

Figure 1 Schematic view of coal combustion in power plants [2]

During the coal combustion, the inorganic components suffer far-reaching transformations that involve melting, agglomeration, condensation and sublima tion. Chemical and structural changes on minerals are caused by the processes of temperature degradation and oxidoreduction [1].

Table 1 Present minerals in coal [1]

\begin{tabular}{||l|l|l||}
\hline \hline Group & Mineral & Composition \\
\hline \multirow{5}{*}{ Clay minerals } & Kaolinite & $\mathrm{Al}_{2} \mathrm{O}_{3} \cdot 2 \mathrm{SiO}_{2} \cdot \mathrm{H}_{2} \mathrm{O}$ \\
& Halloysite & $\mathrm{Al}_{2} \mathrm{O}_{3} \cdot 2 \mathrm{SiO}_{2} \cdot 4 \mathrm{H}_{2} \mathrm{O}$ \\
& Illite & $\mathrm{K}_{2} \mathrm{O} \cdot 2 \mathrm{Al}_{2} \mathrm{O}_{3} \cdot 6 \mathrm{SiO}_{2} \cdot 2 \mathrm{H}_{2} \mathrm{O}$ \\
& Montmorillonite & $\mathrm{AlSi}_{2} \mathrm{O}_{5}(\mathrm{OH}) \cdot \mathrm{nH}_{2} \mathrm{O}$ \\
\hline \multirow{2}{*}{ Sulfide minerals } & Pyrite and marcasite & $\mathrm{FeS}_{2}$ \\
& Pyrrohotite & $\mathrm{Fe}_{5} \mathrm{~S}_{6} \mathrm{do} \mathrm{Fe}_{16} \mathrm{~S}_{17}$ \\
\hline \multirow{5}{*}{ Carbonate minerals } & Calcite & $\mathrm{CaCO}_{3}$ \\
& Dolomite & $(\mathrm{Ca}, \mathrm{Mg})\left(\mathrm{CO}_{3}\right)_{2}$ \\
& Ankerite & $(\mathrm{Ca}, \mathrm{Mg}, \mathrm{Fe}, \mathrm{Mn})\left(\mathrm{CO}_{3}\right)_{2}$ \\
\hline \multirow{2}{*}{ Haloids } & Siderite & $\mathrm{FeCO} 3$ \\
& Halite & $\mathrm{NaCl}$ \\
\hline \hline
\end{tabular}




\begin{tabular}{||l|l|l||}
\hline & Quartz & $\mathrm{SiO}_{2}$ \\
& Gypsum & $\mathrm{CaSO}_{4} \cdot 2 \mathrm{H}_{2} \mathrm{O}$ \\
& Orthoclase & $\mathrm{KAlSi} \mathrm{O}_{8}$ \\
& Biotite & $\mathrm{K}(\mathrm{Mg}, \mathrm{Fe})_{3}\left(\mathrm{AlSi}_{3} \mathrm{O}_{10}\right)(\mathrm{OH})_{2}$ \\
& Diaspora & $\mathrm{Al}_{2} \mathrm{O}_{3} \cdot \mathrm{H}_{2} \mathrm{O}$ \\
& Kyanite & $\mathrm{Al}_{2} \mathrm{O}_{3} \cdot \mathrm{SiO}_{2}$ \\
& Apatite & $9 \mathrm{CaO} \cdot 3 \mathrm{P}_{2} \mathrm{O}_{5} \cdot \mathrm{CaF}_{2}$ \\
\hline
\end{tabular}

The ash is formed in three stages (Figure 2):

- melting of mineral components dispersed in coal

- agglomeration of liquid ash droplets with coal combustion

- formation of of fly ash.

Melting of inorganic compounds is developed in the forst stage, whether they are independent or highly dispersed components present in a coal mass. Size of such molten droplets is about $2 \mu \mathrm{m}$. Molten mineral phase remains in the form of isolated droplets of melt particles on the surface of coke particles. In further combustion, the gradual agglomeration of individual droplets of melt is developed where particles of fly ash occur during cooling [1].

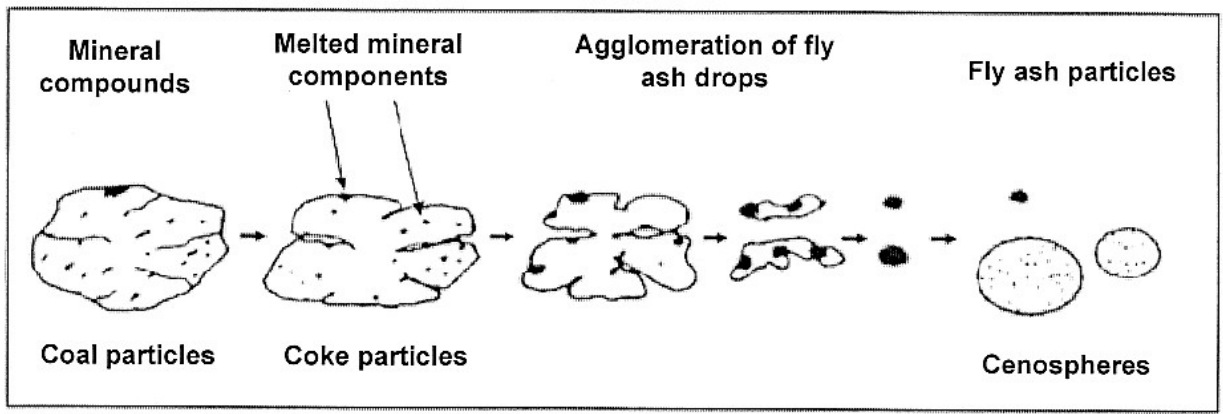

Figure 2 Formation of fly ash

\section{CHEMICAL CONTENT OF FLY ASH}

Fly ashes are usually, according to their chemical composition, extremely aluminosilicate materials [3]. Inorganic constituents in the ash are typical forrocks and soils. These are primarily oxides of silicon, aluminum, iron and calcium, which are by weight $95 \div$ 99\% of ash (Table 2). In addition, the ash typically also contains smaller amounts of compounds of magnesium, titanium, sulfur, sodium and potassium, as well as very small amounts (expressed in millionths parts) of other elements [4-10]. In addition to the mineral (inorganic) compounds, the fly ashes also contain carbon originated from residues of unchanged to partly transformed coal. A very small part of ash is formed from organic compounds, present in coal, such as humates of iron, aluminum and others. 
Table 2 Average chemical content of fly ash [1]

\begin{tabular}{||c|c|c|c|c|c|c|c|c|c||}
\hline \hline \multirow{2}{*}{$\begin{array}{c}\text { Origin } \\
\text { of ash }\end{array}$} & \multicolumn{8}{|c|}{ Chemical component, \% } \\
\cline { 2 - 10 } & $\mathrm{SiO}_{\mathbf{2}}$ & $\mathrm{Al}_{\mathbf{2}} \mathbf{O}_{\mathbf{3}}$ & $\mathbf{F e O}$ & $\mathbf{T i O}_{\mathbf{2}}$ & $\mathbf{C a O}$ & $\mathbf{M g O}$ & $\mathbf{K}_{\mathbf{2}} \mathbf{O}$ & $\mathbf{N a}_{\mathbf{2}} \mathbf{O}$ & $\mathbf{S O}_{\mathbf{3}}$ \\
\hline $\begin{array}{c}\text { Stone } \\
\text { coal }\end{array}$ & $50 \div 57$ & $25 \div 30$ & $3.5 \div 8.0$ & $0 \div 1$ & $2 \div 4$ & $1.5 \div 3.0$ & $2.5 \div 5.0$ & $0.2 \div 2.0$ & $0.5 \div 1.2$ \\
\hline Lignite & $43 \div 60$ & $19 \div 34$ & $3.0 \div 6.0$ & $1 \div 7$ & $4 \div 6$ & $0 \div 2$ & $0 \div 2$ & $0.5 \div 1.0$ & $0 \div 5$ \\
\hline
\end{tabular}

During coal combustion, there is a redistribution of chemical elements. Some evaporate $(\mathrm{Br}, \mathrm{Cl}, \mathrm{F}, \mathrm{Hg}, \mathrm{I})$, but the majority remains in the ash, and they are present in different size classes. Based on extensive research, Vassilev came to the conclusion that in the fly ash the following elements are concentrated [11, 12]:

- litophile elements $(\mathrm{Al}, \mathrm{Ba}, \mathrm{Be}, \mathrm{Ca}$, $\mathrm{Ce}, \mathrm{Cs}$, Dy, Er, Eu, Gd, Hf, Ho, K, $\mathrm{Li}, \mathrm{Lu}, \mathrm{Mg}, \mathrm{Mo}, \mathrm{Na}, \mathrm{Nb}, \mathrm{Nd}, \mathrm{Pr}, \mathrm{Rb}$, $\mathrm{Sm}, \mathrm{Sr}, \mathrm{Ta}, \mathrm{Tb}, \mathrm{Tm}, \mathrm{W}, \mathrm{Y}, \mathrm{Yb}, \mathrm{Zr}$ )

- siderophil elements $(\mathrm{Co}, \mathrm{Cr}, \mathrm{Fe}, \mathrm{Mn}$, $\mathrm{Ni}, \mathrm{Sc}, \mathrm{Ti}, \mathrm{V})$

- chalcophile elements (As, Bi, Cd,
$\mathrm{Cu}, \mathrm{Ga}, \mathrm{Ge}, \mathrm{Pb}, \mathrm{Sb}, \mathrm{Se}, \mathrm{Sn}, \mathrm{Tl}, \mathrm{Zn}$ )

- non-metals $(\mathrm{B}, \mathrm{P}, \mathrm{S})$

- radioactive elements (Th, U).

The mass content of some rare elements in fly ash can be interesting in terms of their valorization from ash.

Chemical composition of fly ash is very important factor that determines a possibility of its use in the construction industry, primarily in the cement industry. The American Standard ASTM C618 [13] defines two classes of ash on the basis of chemical composition or minimum content of the sum of oxides $\mathrm{SiO}_{2}+\mathrm{Al}_{2} \mathrm{O}_{3}+$ $\mathrm{Fe}_{2} \mathrm{O}_{3}$ in the ash (Table 3).

Table 3 Classification of fly ash according to the chemical composition [13]

\begin{tabular}{||l|c|c||}
\hline \multicolumn{1}{|c|}{ Requirements of chemical composition } & Class $\mathbf{F}$ & Class C \\
\hline $\begin{array}{l}\text { Silicon dioxide, aluminium trioxide, ferrix oxide, } \\
\left(\mathrm{SiO}_{2}+\mathrm{Al}_{2} \mathrm{O}_{3}+\mathrm{Fe}_{2} \mathrm{O}_{3}\right), \text { min \% }\end{array}$ & 70 & 50 \\
\hline Sulfur trioxide, $\left(\mathrm{SO}_{3}\right), \max \%$ & 5.0 & 5.0 \\
\hline Moisture content, max \% & 3.0 & 3.0 \\
\hline Alkalis, max \% & 1.5 & 1.5 \\
\hline Loss on ignition, \% & 6.0 & 6.0 \\
\hline
\end{tabular}

Class $\mathrm{F}$ fly ash has low $\mathrm{CaO}$ content (less than $10 \%$ ) and requires an external security of $\mathrm{Ca}(\mathrm{OH})_{2}$ in order to have pozzolanic reaction and development of mechanical properties due to the formation of hydrated calcium silicate (C-S-H). For that reason, this type of ash is a pozzolanic material.

Class $\mathrm{C}$ fly ash has high $\mathrm{CaO}$ content $(>10 \%)$ and presents a hydraulic binder that develops the mechanical properties without the absence of an external source of $\mathrm{Ca}(\mathrm{OH})_{2}$ [14-16].

The current Serbian Standard SRPS B.C1.018 [17] classifies the fly ash in artificial pozzolans and divides it into two categories: siliceous fly ash (V) and calcareous fly ash (W). For siliceous fly ash, the content of reactive $\mathrm{SiO}_{2}$ (Ts) is determined, and based on this, there are three different types 
of ash. These are the type I (Ts $>35.00 \%)$, type II $(30.00 \%<\mathrm{Ts}<35.00 \%)$ and type III $(25.00 \%<\mathrm{Ts}<30.00 \%)$.

In addition, the same standard also defines maximum content of reactive calcium oxide of $10 \%$, where the amount of free $\mathrm{CaO}$ in the ash can not be higher than $2.50 \%$. Ignition loss is limited to maximum of 5 (7)\%.

Based on practical experience, minimum $40 \%$ of $\mathrm{SiO}_{2}$ is adopted, as a condition of silicon dioxide content in pozzolanic active substances. Thereby, high total content of acidic oxides $\left(\mathrm{SiO}_{2}+\mathrm{Al}_{2} \mathrm{O}_{3}+\mathrm{Fe}_{2} \mathrm{O}_{3}\right)$ is characterized by aluminosilicate matters of distinct pozzolanic properties, and high content of basic oxides $(\mathrm{CaO}, \mathrm{MgO})$ may adversely affect the pozzolanic activity.

The European Standard EN 450-1 [18] defines the following conditions in terms of chemical composition of siliceous fly ash:

- maximum loss on ignition of $5 \%$ for category A

- loss on ignition of 2 to $7 \%$ for category B

- loss on ignition of 4 to $9 \%$ for category $\mathrm{C}$

- maximum content of chemical components (chlorides max. $0.1 \%, \mathrm{SO}_{3}$ max. $3.0 \%$, free $\mathrm{CaO} \max 2.5 \%$, $\mathrm{CaO}$ reactive max. $10 \%$ )

- total content of oxides $\mathrm{SiO}_{2}+\mathrm{Al}_{2} \mathrm{O}_{3}$ $+\mathrm{Fe}_{2} \mathrm{O}_{3} \min .70 \%$

- total alkali content max. $5 \%$.

\section{MINERALOGICAL AND MORPHO- LOGICAL CONTENT OF FLY ASH}

According to the mineralogical composition of the fly ash can be divided into three types of components, grouped as inorganic, organic and fluid part (Table 4) [19].

Figure 3 shows the SEM appearance of various particles that are present in fly ash.

Inorganic part is represented by an amorphous (non-crystalline) and crystalline phase, which can be magnetic and nonmagnetic.

Amorphous phase includes a glassy amorphous mass that consists mainly of Al$\mathrm{Si}$ compounds in various modification forms of [20]. Mass content of this phase in fly ash depends on temperature of coal combustion as well as cooling rate of ash and may be in the range of $66 \div 96 \%$. Glassy, amorphous structure is actually the main carrier of pozzolanic properties of fly ash [21].

Table 4 Morphological content of fly ash [19]

\begin{tabular}{||l|l||}
\hline \hline & $\begin{array}{l}\text { Non-crystalline (amorphous) components } \\
\text { - Spherical and spheroidal particles (thick, bubbly, ceno spheres, plero } \\
\text { spheres, derma spheres, ferro spheres, etc.). } \\
\text { - Angled and irregular particles (thick, hollow, bubbly, thready, ag- } \\
\text { glomerates, etc.). }\end{array}$ \\
\cline { 2 - 3 } INORGANIC PART & $\begin{array}{l}\text { Crystalline (mineral) components } \\
\text { - Crystals and aggregates } \\
\text { - Grains and grapes } \\
\text { - Ferro spheres and feri spheres } \\
\text { - Skeletal spheres and spheroids } \\
\text { - Agglomerates, etc. }\end{array}$ \\
\hline
\end{tabular}




\begin{tabular}{||l|l||}
\hline \multirow{5}{*}{ ORGANIC PART } & $\begin{array}{l}\text { Carbon components } \\
\text { - Slightly altered coal particle (thick, square, irregular, round, rough, } \\
\text { agglomerates, etc.). }\end{array}$ \\
\cline { 2 - 3 } & Semi-coke components \\
\cline { 2 - 3 } FLUID PART & $\begin{array}{l}\text { Coke components } \\
- \text { Spherical, spheroidal, square and irregular particles (thick, hollow, } \\
\text { bubbly, rough, skeletal, agglomerates, etc.). }\end{array}$ \\
\hline $\begin{array}{l}\text { - Gaseous-liquid inclusions in particles formed by combustion of } \\
\text { organic and inorganic matter from coal }\end{array}$ \\
\hline
\end{tabular}

Morphologically, the amorphous part of fly ash consists of spherical and spheroidal and irregular particles. Microspheres (spheres and spheroids) are the result of slow, partial or complete melting of coal minerals such as quartz, clay minerals, chlorites, mica, feldspar and other minerals with low melting point. Volume fraction of spheres and spheroids in the ash varies in the range of $10 \div 80 \%$, and their share increases with increasing fineness of ash. Thick and bubbly spheres, ceno spheres and plero pspheres are the most often representatives, while derma spheres and ferro spheres are rarely present. Their size is in the range $1 \div 50 \mu \mathrm{m}$ [14].

Thick and bubbly spheres (Figure $3 \mathrm{a}, \mathrm{c}$ ) originate from melt droplets of various minerals of melt from which complete (thick) or partially (bubbly) volatile components are evaporated.

Ceno spheres (Figure $3 \mathrm{~b}, \mathrm{~d}, \mathrm{e}$ ) are hollow spheres with thin walls that are sometimes divided into tiny fragments. Their sizes typically range from $10 \div 250 \mu \mathrm{m}$ and they are generally larger than thick and bubbly spheres. The interior of a sphere is filled with gas and gas generated during the combustion process as the result of decomposition of organic matter, carbonates, sulfides, sulfates, hydrosilicates and evaporation the hygroscopic moisture from coal. The presence and persistence ceno spheres can be explained by high value of viscosity of molten covering and possibility of retention the gas bubbles during the hardening period. The amount ceno spheres in the ash ranges between $15-20 \%$ (vol).

Plero spheres (Figure $3 \mathrm{f}$ ) are hollow spheres filled with ceno spheres of small sizes.

Derma spheres (Fig. 3 g) are plero spheres with crystal nucleus of mullite, hematite and other minerals and they are covered with coating of aluminosilicate glass.

Ferro spheres (Figure $3 \mathrm{~h}, \mathrm{i}, \mathrm{j}$ ) are ironrich spheres whose basic structure is of crystalline or amorphous material. Iron in ferro spheres is mainly present in the form of ferrispinels (complex solid solution based on $\mathrm{Fe}_{3} \mathrm{O}_{4}$ with impurities of $\mathrm{Mg}, \mathrm{Mn}, \mathrm{Ca}$ ). Where the internal material of ferro spheres is determined by morphology of ferrispinel aggregates, that are in the glassy phase. In addition, the feero spheres may also include hematite $\left(\alpha-\mathrm{Fe}_{2} \mathrm{O}_{3}\right)$, maghemite $\left(\gamma-\mathrm{Fe}_{2} \mathrm{O}_{3}\right)$, magnetite $\left(\mathrm{Fe}_{3} \mathrm{O}_{4}\right)$, trevorite $\left(\mathrm{NiFe}_{2} \mathrm{O}_{4}\right)$, ulvospinel $\left(\mathrm{TiFe}_{2} \mathrm{O}_{4}\right)$, jacobsite $\left(\mathrm{MnFe}_{2} \mathrm{O}_{4}\right)$ and many other minerals, as well as the basic glassy aluminosilicate phase.[22, 23]. The majority of ferro spheres have nearly perfect spherical shape. Ferro spheres may be hollow and filled, and their diameter varies from a few microns up to $300 \mu \mathrm{m}$ [22]. 


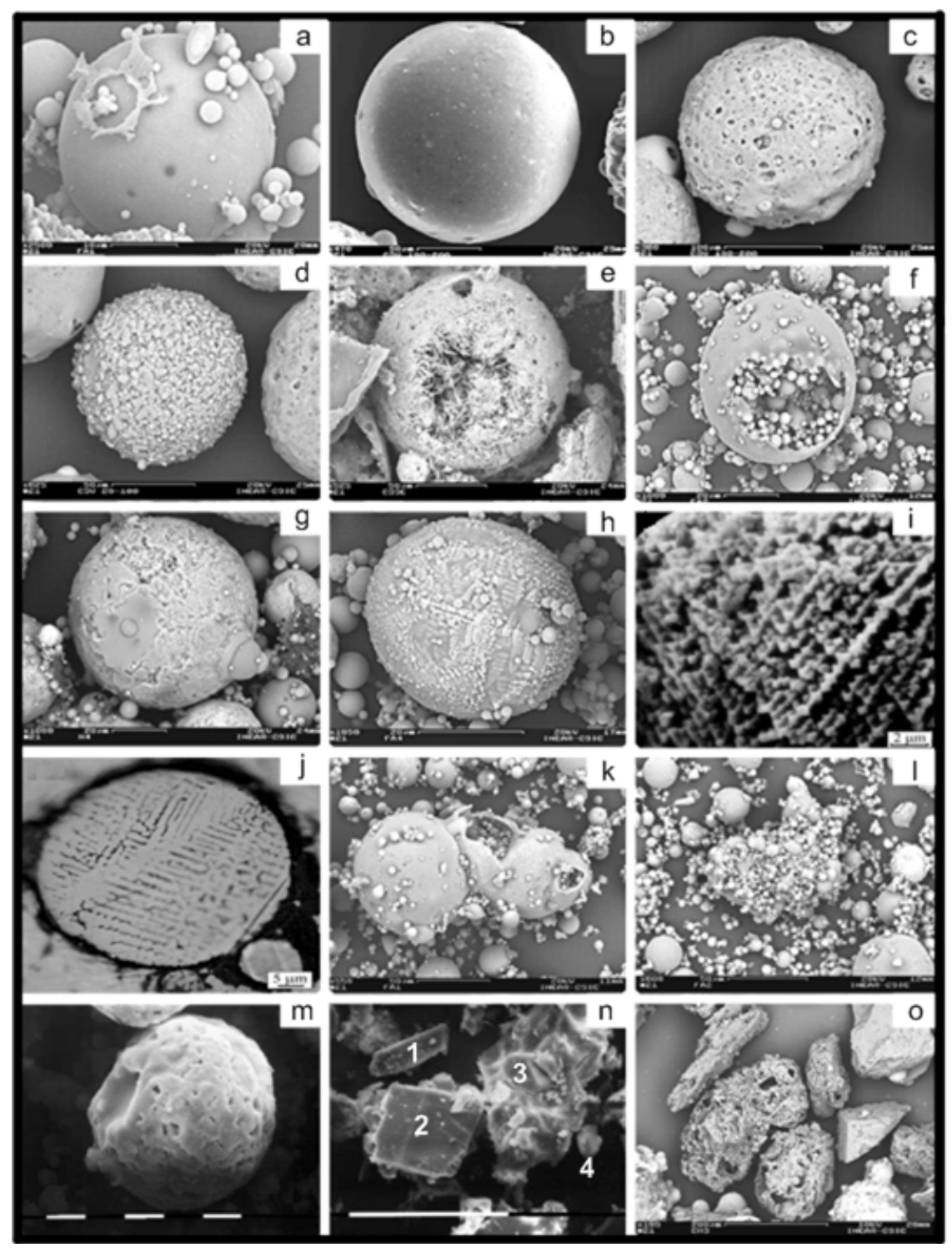

Figure 3 SEM view of present particles in the fly ash:

$a$ - aluminosilicate glassy sphere, $b$ - smooth aluminosilicate ceno sphere, $c$ - bubbly aluminosilicate ceno sphere, $d$-aluminosilicate ceno sphere with crystals of calcite and dolomite on surface, $e$ - crystal structure of mullite-cristobalite-quartz in the wall of aluminosilicate ceno sphere, $f$ - aluminosilicate glassy plero sphere, $g$-derma sphere (larnite covered with aluminosilicate glass) $h$-ferro spherea with dendritic crystals of magnetite in the aluminosilicate glass, andsurface of ferro sphere (oriented chains of ferrospinel in the glassy phase), $j$-internal structure of ferro sphere, $k$-aluminosilicate glassy sphere (right) and porous aluminosilicate spheroid (left), $l$ - glassy agglomerate, m-plagioclass spheroid, $n$-gypsum (1), calcite (2), calcite covered with Ca-Mg-Na-K phase (3), opal (4), o- different types of particles of organic origin [22 5,6,12] 
Spheroids (Figure $3 \mathrm{k}, \mathrm{m}$ ) cannot be significantly different from spheres, but they look more porous and bubbly. Their size is in the range $10 \div 80 \mu \mathrm{m}$. Spheroids contain two, three or more areas where gas bubbles are arranged [19].

Angular and irregular particles (Figure 3 1) are also formed by melting and cooling of mineral components. They may be compact or porous, or filled with gas bubbles. They often appear in the form of grapes caused by clustering and agglomeration of particles in the plastic phase. Their size ranges $60 \div 500 \mu \mathrm{m}[19]$.
Crystal phase includes: quartz, mullite, cristobalite, calcite, anhydrite, kaolinite, feldspar and iron oxides (magnetite, maghemite, hematite). In addition to these minerals, many others can be specified that occur less frequently and to a lesser extent (Figure 3 n; Table 5).

Organic part consists of a number of mineral neo-formation of the original coal to semi-coke and coke (Figure 3 o). Their content corresponds to the value of loss on ignition of dry fly ash sample [14].

Fluid matters include moisture, gases and gas-liquid inclusions, which are bonded to organic and inorganic part.

Table 5 Mineralogical composition of the crystalline component of fly ash [19]

\begin{tabular}{|c|l||}
\hline Silicates & $\begin{array}{l}\text { quartz, cristobalite, kaolinite, mullite, andalusite, plagioclase, potassium feld- } \\
\text { spar, olivine, pyroxene, amphibole, zircon, chlorite, mica, vermiculite, talc, } \\
\text { rankinite, wollastonite, larnite, melilite, monticellite, Ca-Mn silicates }\end{array}$ \\
\hline $\begin{array}{c}\text { Oxides and hy- } \\
\text { droxides }\end{array}$ & $\begin{array}{l}\text { magnetite, maghemite, hematite, limonite, magnesioferrite, ilmenite, spinel, } \\
\text { ferrispinel, chromite, chalcophanite, pyrolusite, cuprite, tenorite, zincite, } \\
\text { rutile, anatase, brokite, lime, portlandite, periclass, brucite, corundum, } \gamma- \\
\mathrm{Al}_{2} \mathrm{O}_{3}, \mathrm{Al} \text { hydroxides, } \mathrm{W}-\mathrm{Nb}-\mathrm{Pb} \text { oxides }\end{array}$ \\
\hline Sulfates & gypsum, anhydrite, Fe sulfates, $\mathrm{Mg}$ sulfates, Na-K sulfatee, barytee \\
\hline Carbonates & calcite, siderite, manganocalcite, dolomite, cerussite, witherite \\
\hline Phosphates & apatite, svanbergite, vivianite, goyasite \\
\hline Sulfides & pyrrhotine, pyrite, Pb-Sb sulfides, chalcocite \\
\hline Others & glass, organic matters, Fe carbide, graphite, scheelite \\
\hline
\end{tabular}

\section{CONCLUSION}

Fly ash is a heterogeneous mixture of particles of different physical, chemical, mineralogical, and morphological characteristics formed by coal combustion in power plants. Characteristics of fly ash are primarily determined by the quality of burnt coal; first of all stage composition of inorganic component in coal and its transformations during combustion. In addition, the technology of combustion process also affects the quality of fly ash.
Fly ashes are usually, according to their chemical composition, the extremely aluminosilicate matters, while according to the mineralogical composition, it is possible to divide three types of components, grouped as inorganic, organic and fluid part. The inorganic part is represented by amorphous and crystalline phase. The organic part consists of a number of mineral neo-formation of the original coal to semi-coke and coke, until the fluid matters consist of moisture, gases and gas-liquid inclusions associated with fly ash particles. 


\section{REFERENCES}

[1] Fečko P., Kušnierovà M., Raclavskà H., Čablík V., Lyčkovà B: Fly ash, VŠB - Technical University of Ostrava (2005), p. 191

[2] Ilić I: Possibility of Application the Micronized and Classified Electrofilter Ash as an Additive for Production the Construction Materials, M.S. Thesis, Faculty of Mining and Geology Belgrade (2009), p. 124 (in Serbian)

[3] Kostović M., Simović I., Kostović N, Bužalo A., Some Aspecst of Use the Electrofilter Ash in the Construction, Proceedings: III Symposium "Recycling Technologies and Sustainable Development", Sokobanja (2008), pp. 97-103 (in Serbian)

[4] Okada T., Tomikawa H: Effects of chemical composition of fly ash on efficiency of metal separation in ashmelting of municipal solid waste, Waste Management, Volume 33, Issue 3 (2013), pp. 605-614

[5] Vassilev S. V., Menendez R., Alvarez D., Diaz-Somoano M., MartinezTarazona M.R. Phase-mineral and chemical composition of coal fly ashes as a basis for their multicomponent utilization. 1. Characterization of feed coals and fly ashes, Fuel, Vol. 82 (2003), pp. 1793-1811

[6] Vassilev S. V., Menendez R., DiazSomoano M., Martinez-Tarazona M. R. Phase-mineral and chemical composition of coal fly ashes as a basis for their multicomponent utilization. 2. Characterization of ceramic cenosphere and salt concentrates, Fuel, Vol. 83 (2004), pp. 585-603

[7] Vassilev S. V., Vassileva C. G.: A new approach for the classification of coal fly ashes based on their origin composition, properties, and beha- viour, Fuel Volume 86, Issues 10-11 (2007), pp. 1490-1512

[8] Temuujin J., Rickard W., Van Riessen A: Characterization of various fly ashes for preparation of geopolymers with advanced applications, Advanced Powder Technology, Volume 24, Issue 2 (2013), pp. 495-498

[9] Ural S: Comparison of fly ash properties from Afsin-Elbistan coal basin, Turkey, Journal of Hazardous Materials, Volume 119, Issues 1-3 (2005), pp. 85-92

[10] Sarkar A., Rano R., Udaybhanu G., Basu A.K: A comprehensive characterisation of fly ash from a thermal power plant in Eastern India, Fuel Processing Technology, Volume 87, Issue 3 (2006), pp. 259-277

[11] Vassilev S. V., Vassileva C. G. Geochemistry of coals, coal ashes and combustion wastes from coal-fired power stations, Fuel Processing Technology, Vol. 51, (1997), pp. 19-45

[12] Vassilev S. V., Vassileva C. G., Karayigit A. I., Bulut Y., Alastuey A., Querol X: Phase-mineral and chemical composition of composite samples from feed coals, bottom ashes and fly ashes at the Soma power station, Turkey, International Journal of Coal Geology, Vol. 61 (2005), pp. 35-63

[13] Standard ASTM C618

[14] Stefanović G., Phenomena and Mechanisms in the System of Portland Cement - Fly Ash, Depending on Characteristics of Fly Ash, Ph.D. Thesis, Faculty of Mechanical Engineering, Niš (2006), (in Serbian)

[15] Das S. K: A simplified model for prediction of pozzolanic characteristics of fly ash, based on chemical composition, Cement and Concrete Research, Volume 36, Issue 10 (2006), pp. 1827-1832 
[16] Sharonova O. M., Solovyov L. A., Oreshkina N. A., Yumashev V. V., Anshits A. G: Composition of highcalcium fly ash middlings selectively sampled from ash collection facility and prospect of their utilization as component of cementing materials, Fuel Processing Technology, Volume 91, Issue 6 (2010), pp. 573-581

[17] Standard SRPS B.C1.018

[18] Standard EN 450-1

[19] Vassilev S. V., Vassileva C. G: Mineralogy of combustion wastes from coal-fired power stations, Fuel Processing Technology, Vol. 47 (1996), pp. 261-280

[20] Ward C. R., French D: Determination of glass content and estimation of glass composition in fly ash using quantitative X-ray diffractometry,
Fuel, Volume 85, Issue 16 (2006), pp. 2268-2277

[21] Jovanović I., Bugarinović S., Obradović Lj.: Mechanical characteristics of mortar containing fly ash treated by different physical methods, Mining Enginering 4(2012), pp. 173-184

[22] Sokol E. V., Kalugin V. M., Nigmatulina E. N., Volkova N. I., Frenkel A. E., Maksimova N. V: Ferrospheres from fly ashes of Chelyabinsk coals: chemical composition, morphology and formation conditions, Fuel, Vol. 81 (2002), pp. 867-876

[23] Zhao Y., Zhang J., Sun J., Bai X., Zheng C: Mineralogy, chemical composition, and microstructure of ferrospheres in fly ashes from coal combustion, Energy Fuels, Vol 20 (2006), pp. 1490-1497 


\begin{tabular}{ll}
\hline \hline INSTITUT ZA RUDARSTVO I METALURGIJU BOR & ISSN: 2334-8836 \\
& UDK: 622 \\
\hline \hline
\end{tabular}

Ivana Jovanovic , Mile Bugarin", Srđana Magdalinovic *

\section{PREGLED SAVREMENIH SVETSKIH ISTRAŽIVANJA O KARAKTERISTIKAMA LETEĆEG PEPELA KAO SEKUNDARNE MINERALNE SIROVINE; DEO $1^{* *}$}

Izvod

U današnje vreme postoji sve veća tendencija da se leteći pepeo iz termoelektrana ne razmatra samo kao otpadni materijal koji predstavlja balast, već i kao značajna sekundarna sirovina koja se može korisno upotrebiti u različitim granama privrede. Stoga je u ovom radu dat opis osnovnih karakteristika letećeg pepela, kao što su njegov hemijski, mineraloški i morfološki sastav. U zavisnosti od ovih karakteristika zavisi i mogućnost primene letećeg pepela. Pored toga, u radu je dat prikaz nekih standardnih normi koje su propisane domaćim i svetskim standardima, a odnose se na kvalitet lećeg pepela u pogledu njegovog hemijskog sastava.

Ključne reči: leteći pepeo, sekundarne mineralne sirovine

\section{UVOD}

Leteći pepeo je heterogena mešavina čestica različitih fizičkih, hemijskih, mineraloških i morfoloških osobina, koja nastaje sagorevanjem uglja u termoelektranama i čije su karakteristike određene kvalitetom izgorelog uglja, tehnologijom sagorevanja i uslovima sagorevanja. U literaturi postoji više predloga za sistematizaciju i klasifikaciju letećeg pepela. Prema Internacionalnom sistemu klasifikacije, podela letećih pepela izvršena je na principu sadržaja $\mathrm{SiO}_{2}$ i $\mathrm{Al}_{2} \mathrm{O}_{3}$, u četiri osnovne grupe [1]. To su:

- Alumosilikatni (tip I), kod koga je maseni odnos sadržaja oksida $\mathrm{SiO}_{2} / \mathrm{Al}_{2} \mathrm{O}_{3}$ $>2$, sadržaj $\mathrm{CaO}$ manji od $15 \%$, dok se sadržaj $\mathrm{SO}_{3}$ ne definiše.
- Silikatno-aluminatni (tip II), pri čemu je odnos $\mathrm{SiO}_{2} / \mathrm{Al}_{2} \mathrm{O}_{3}<2$, sadržaj $\mathrm{CaO}$ manji od $15 \%$, a sadržaj $\mathrm{SO}_{3}$ manji od $3 \%$.

- Sulfatno-alkalni (tip III), koji sadrži više od $15 \% \mathrm{CaO}$ i više od $3 \% \mathrm{SO}_{3}$, dok maseni onos $\mathrm{SiO}_{2}$ i $\mathrm{Al}_{2} \mathrm{O}_{3}$ nije definisan.

- Kalcitski (tip IV) sa visokim sadržajem $\mathrm{CaO}(>15 \%)$ i niskim sadržajem sulfata $(<3 \%)$, pri čemu se odnos $\mathrm{SiO}_{2} / \mathrm{Al}_{2} \mathrm{O}_{3}$ takođe ne definiše.

\section{NASTANAK LETEĆEG PEPELA}

Leteći pepeo predstavlja najfiniju frakciju koja zaostaje nakon sagorevanja uglja u termalnim postrojenjima (slika 1).

\footnotetext{
* Institut za rudarstvo i metalurgiju Bor, Zeleni bulevar 35, Bor

** Ovaj rad je proistekao kao rezultat Projekta br. 34006 „,Mehanohemijski tretman nedovoljno kvalitetnih mineralnih sirovina“, $i$ Projekta br. 37001 “Uticaj rudarskog otpada iz RTB Bor na zagađenje vodotokova, sa predlogom mera i postupaka za smanjenje štetnog dejstva na životnu sredinu“, koje finansira Ministarstvo prosvete, nauke i tehnološkog razvoja Republike Srbije.
} 
Izdvaja se na elektrofilterima, a veličina zrna mu se uglavnom kreće u rasponu $0 \div 1 \mathrm{~mm}$. Karakteristike letećeg pepela prvenstveno su uslovljene faznim sastavom neorganske komponente uglja i njenim transformacijama $\mathrm{u}$ toku sagorevanja. Neorgansku komponentu uglja čine nečistoće koje su visoko dispergovane u ugljenoj masi, odnosno čistoj ugljenoj supstanci organske strukture [2]. Ove komponente su delimično i hemijski vezane za ugljenu masu.

Do $95 \%$ nečistoća čine tri glavne grupe minerala - alumosilikatni (tj. minerali gline), sulfidni i karbonatni minerali. U tabeli 1 su prikazani uobičajeni minerali, koji se nalaze u uglju [1].

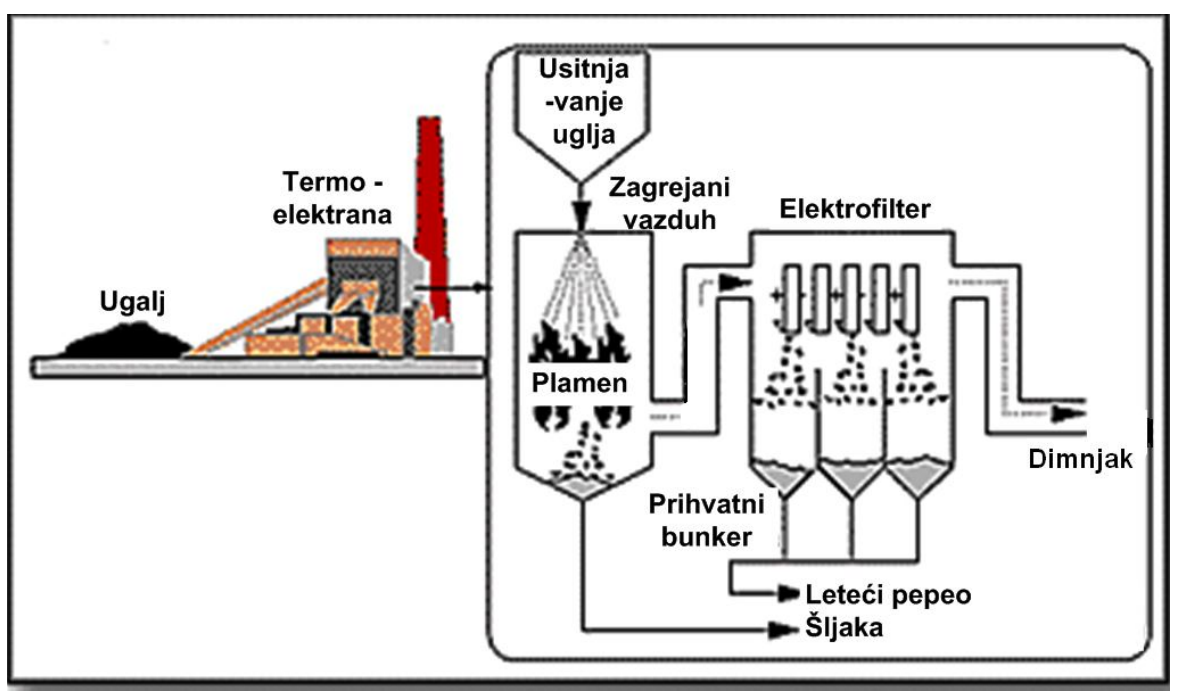

SI. 1. Šematski prikaz sagorevanja uglja u termoelektranama [2]

U toku sagorevanja uglja neorganske komponente trpe dalekosežne transformacije koje podrazumevaju topljenje, aglomeraciju, kondenzaciju i sublima- ciju. Hemijske i strukturne promene na mineralima uslovljene su procesima temperaturne degradacije i oksido-redukcije [1].

Tabela 1. Minerali koji su prisutni u uglju [1]

\begin{tabular}{||l|l|l||}
\hline Grupa & Mineral & Sastav \\
\hline \multirow{4}{*}{ Minerali gline } & Kaolinit & $\mathrm{Al}_{2} \mathrm{O}_{3} \cdot 2 \mathrm{SiO}_{2} \cdot \mathrm{H}_{2} \mathrm{O}$ \\
& Halojzit & $\mathrm{Al}_{2} \mathrm{O}_{3} \cdot 2 \mathrm{SiO}_{2} \cdot 4 \mathrm{H}_{2} \mathrm{O}$ \\
& Ilit & $\mathrm{K}_{2} \mathrm{O} \cdot 2 \mathrm{Al}_{2} \mathrm{O}_{3} \cdot 6 \mathrm{SiO}_{2} \cdot 2 \mathrm{H}_{2} \mathrm{O}$ \\
& Montmorilonit & $\mathrm{AlSi}_{2} \mathrm{O}_{5}(\mathrm{OH}) \cdot \mathrm{nH}_{2} \mathrm{O}$ \\
\hline \multirow{3}{*}{ Sulfdni minerali } & Pirit i markasit & $\mathrm{FeS}_{2}$ \\
& Pirotin & $\mathrm{Fe}_{5} \mathrm{~S}_{6} \mathrm{do} \mathrm{Fe}_{16} \mathrm{~S}_{17}$ \\
\hline \multirow{3}{*}{ Karbonatni minerali } & Kalcit & $\mathrm{CaCO}_{3}$ \\
& Dolomit & $(\mathrm{Ca}, \mathrm{Mg})\left(\mathrm{CO}_{3}\right)_{2}$ \\
& Ankerit & $(\mathrm{Ca}, \mathrm{Mg}, \mathrm{Fe}, \mathrm{Mn})\left(\mathrm{CO}_{3}\right)_{2}$ \\
\hline
\end{tabular}




\begin{tabular}{||l|l|l||}
\hline Haloidi & Halit & $\mathrm{NaCl}$ \\
& Silvit & $\mathrm{KCl}$ \\
\hline & Kvarc & $\mathrm{SiO}$ \\
& Gips & $\mathrm{CaSO}_{4} \cdot 2 \mathrm{H}_{2} \mathrm{O}$ \\
& Ortoklas & $\mathrm{KAlSi} \mathrm{O}_{8}$ \\
& Biotit & $\mathrm{K}(\mathrm{Mg}, \mathrm{Fe})_{3}\left(\mathrm{AlSi}_{3} \mathrm{O}_{10}\right)(\mathrm{OH})_{2}$ \\
& Diaspor & $\mathrm{Al}_{2} \mathrm{O}_{3} \cdot \mathrm{H}_{2} \mathrm{O}$ \\
& Kianit & $\mathrm{Al}_{2} \mathrm{O}_{3} \cdot \mathrm{SiO}_{2}$ \\
& Apatit & $9 \mathrm{CaO} \cdot 3 \mathrm{P}_{2} \mathrm{O}_{5} \cdot \mathrm{CaF}_{2}$ \\
\hline
\end{tabular}

Pepeo se formira u tri stadijuma (slika 2):

- topljenje mineralnih komponenti dispergovanih u uglju,

- aglomeracija tečnih kapljica pepela uz sagorevanje uglja,

- obrazovanje letećeg pepela.

U prvom stadijumu se odvija topljenje neorganskih jedinjenja, bilo da su to neza- visne primese ili visoko dispergovane komponente koje se nalaze u ugljenoj masi. Veličina ovako istopljenih kapljica iznosi oko $2 \mu \mathrm{m}$. Istopljena mineralna faza ostaje $u$ obliku izolovanih kapljica rastopa na površini čestica koksa. U toku daljeg sagorevanja dolazi do postepene aglomeracije pojedinačnih kapljica rastopa, od kojih u toku hlađenja nastaju čestice letećeg pepela [1].

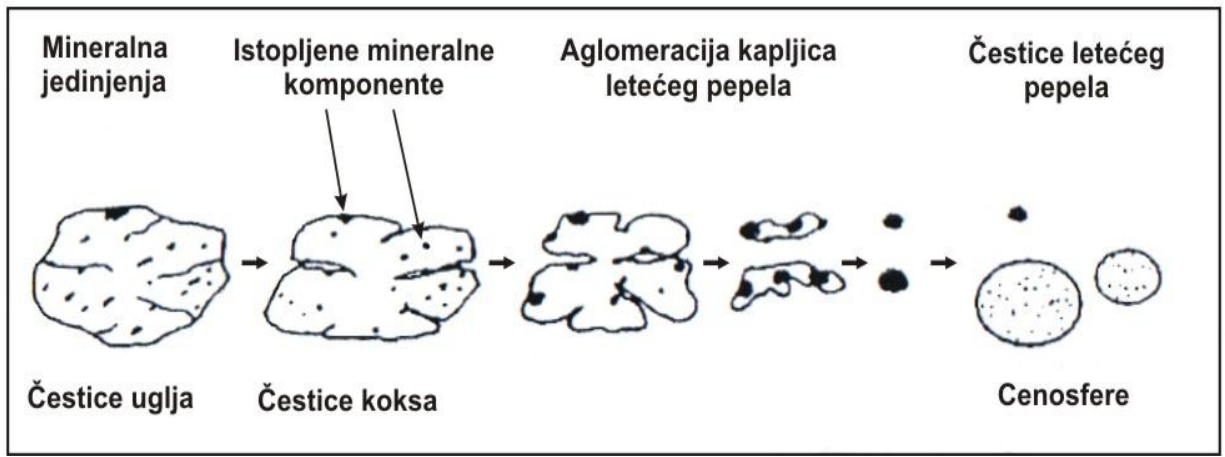

Sl. 2. Nastanak letećeg pepela

\section{HEMIJSKI SASTAV LETEĆEG PEPELA}

Leteći pepeli su, najčešće, po svom hemijskom sastavu izrazito alumosilikatne materije [3]. Neorganski sastojci u pepelu su tipični za stene i zemljišta. To su pre svega oksidi silicijuma, aluminijuma, gvožđa i kalcijuma, koji čine maseno $95 \div 99 \%$ pepela (tabela 2). Pored toga, pepeo po pravilu sadrži i manje količine jedinjenja magnezijuma, titana, sumpora, natrijuma i kalijuma, kao i veoma male količine (izražene u milionitim delovima) drugih elemenata [4-10]. Pored mineralnih (neor- 
ganskih) sastojaka, leteći pepeli sadrže i ugljenik koji potiče od ostataka neizmenjenog do delimično transformisanog uglja.
Veoma mali deo pepela nastaje od organskih jedinjenja prisutnih u uglju, kao što su humati gvožđa, aluminijuma i dr.

Tabela 2. Prosečan hemijski sastav letećeg pepela [1]

\begin{tabular}{|c|c|c|c|c|c|c|c|c|c|}
\hline \multirow{2}{*}{$\begin{array}{l}\text { Poreklo } \\
\text { pepela }\end{array}$} & \multicolumn{9}{|c|}{ Hemijska komponenta, \% } \\
\hline & $\mathrm{SiO}_{2}$ & $\mathrm{Al}_{2} \mathrm{O}_{3}$ & $\mathrm{FeO}$ & $\mathrm{TiO}_{2}$ & $\mathrm{CaO}$ & MgO & $\mathbf{K}_{2} \mathbf{O}$ & $\mathrm{Na}_{2} \mathrm{O}$ & $\mathrm{SO}_{3}$ \\
\hline $\begin{array}{c}\text { Kameni } \\
\text { ugalj }\end{array}$ & $50 \div 57$ & $25 \div 30$ & $3,5 \div 8,0$ & $0 \div 1$ & $2 \div 4$ & $1,5 \div 3,0$ & $2,5 \div 5,0$ & $0,2 \div 2,0$ & $0,5 \div 1,2$ \\
\hline Lignit & $43 \div 60$ & $19 \div 34$ & $3,0 \div 6,0$ & $1 \div 7$ & $4 \div 6$ & $0 \div 2$ & $0 \div 2$ & $0,5 \div 1,0$ & $0 \div 5$ \\
\hline
\end{tabular}

Prilikom sagorevanja uglja dolazi do preraspodele hemijskih elemenata. Neki isparavaju $(\mathrm{Br}, \mathrm{Cl}, \mathrm{F}, \mathrm{Hg}, \mathrm{I})$, ali većina ostaje $\mathrm{u}$ pepelu $\mathrm{i}$ to prisutna u različitim klasama krupnoće. Na osnovu opsežnih istraživanja Vassilev je došao do zaključka da se u letećim pepelima koncentrišu sledeći elementi $[11,12]$ :

- litofilni elementi (Al, Ba, Be, Ca, Ce, Cs, Dy, Er, Eu, Gd, Hf, Ho, K, Li, Lu, $\mathrm{Mg}, \mathrm{Mo}, \mathrm{Na}, \mathrm{Nb}, \mathrm{Nd}, \mathrm{Pr}, \mathrm{Rb}, \mathrm{Sm}, \mathrm{Sr}$, Ta, Tb, Tm, W, Y, Yb, Zr)

- siderofilni elementi (Co, Cr, Fe, Mn, Ni, Sc, Ti, V)

- halkofilni elementi (As, Bi, Cd, Cu,
$\mathrm{Ga}, \mathrm{Ge}, \mathrm{Pb}, \mathrm{Sb}, \mathrm{Se}, \mathrm{Sn}, \mathrm{Tl}, \mathrm{Zn})$

- nemetali (B, P, S)

- radioaktivni elementi (Th, U)

Maseni sadržaj pojedinih retkih elemenata u letećem pepelu može da bude interesantan sa aspekta njihove valorizacije iz pepela.

Hemijski sastav letećeg pepela je veoma bitan faktor koji određuje mogućnost njegove primene $u$ građevinarstvu, prvenstveno $\mathrm{u}$ industriji cementa. Američki standard ASTM C618 [13] definiše dve klase pepela na osnovu hemijskog sastava, odnosno prema minimalnom sadržaju zbira oksida $\mathrm{SiO}_{2}+\mathrm{Al}_{2} \mathrm{O}_{3}+\mathrm{Fe}_{2} \mathrm{O}_{3}$ u pepelu (tabela 3).

Tabela 3. Klasifikacija letećeg pepela prema hemijskom sastavu [13]

\begin{tabular}{||l|c|c||}
\hline \multicolumn{1}{|c|}{ Zahtevi hemijskog sastava } & Klasa F & Klasa C \\
\hline $\begin{array}{l}\text { Silicijum dioksid, aluminijum trioksid, feri oksid, } \\
\left(\mathrm{SiO}_{2}+\mathrm{Al}_{2} \mathrm{O}_{3}+\mathrm{Fe}_{2} \mathrm{O}_{3}\right), \min \%\end{array}$ & 70 & 50 \\
\hline Sumpor trioksid, $\left(\mathrm{SO}_{3}\right), \max \%$ & 5,0 & 5,0 \\
\hline Sadržaj vlage, max \% & 3,0 & 3,0 \\
\hline Alkalije, max \% & 1,5 & 1,5 \\
\hline Gubitak žarenjem, \% & 6,0 & 6,0 \\
\hline
\end{tabular}

Leteći pepeo klase $\mathrm{F}$ ima nizak sadržaj $\mathrm{CaO}$ (manje od 10\%) i zahteva eksterno obezbeđenje $\mathrm{Ca}(\mathrm{OH})_{2}$ da bi došlo do pucolanskih reakcija i razvijanja mehaničkih osobina usled formiranja hidrati- sanog kalcijum silikata (C-S-H). Zato ova vrsta pepela predstavlja pucolanski materijal.

Leteći pepeo klase $\mathrm{C}$ ima visok sadržaj $\mathrm{CaO}(>10 \%)$ i predstavlja hidraulično 
vezivo koje razvija mehaničke karakteristike bez prisustva eksternog izvora $\mathrm{Ca}(\mathrm{OH})_{2}$ [14-16].

Važeći srpski standard SRPS B.C1.018 [17] svrstava leteći pepeo u veštačke pucolane i deli ga na dve kategorije: silikatni leteći pepeo (V) i karbonatni leteći pepeo (W). Za silikatne leteće pepele utvrđuje se sadržaj reaktivnog $\mathrm{SiO}_{2}$ (Ts), i na osnovu toga se razlikuju tri tipa pepela. To su tip I (Ts > 35,00\%), tip II $(30,00 \%<$ Ts < $35,00 \%)$ i tip III $(25,00 \%<$ Ts $<30,00 \%)$.

Pored toga, isti standard definiše i maksimalni sadržaj reaktivnog kalcijum oksida od 10\%, pri čemu količina slobodnog $\mathrm{CaO}$ u pepelu ne sme biti veća od $2,50 \%$. Gubitak žarenjem se ograničava na maksimalnih 5 (7)\%.

$\mathrm{Na}$ osnovu iskustva u praksi, usvaja se minimalno $40 \% \mathrm{SiO}_{2}$, kao uslov za sadržaj silicijum dioksida u pucolanskim aktivnim materijama. Pri tom, visok ukupan sadržaj kiselih oksida $\left(\mathrm{SiO}_{2}+\mathrm{Al}_{2} \mathrm{O}_{3}+\mathrm{Fe}_{2} \mathrm{O}_{3}\right)$ karakteriše alumosilikatne materije izrazitih pucolanskih osobina, a visok sadržaj baznih oksida $(\mathrm{CaO}, \mathrm{MgO})$ može negativno uticati na pucolansku aktivnost.

Evropski standard EN 450-1 [18] definiše sledeće uslove u pogledu hemijskog sastava silikatnog letećeg pepela:

- maksimalni gubitak žarenjem od 5\% za kategoriju A,

- gubitak žarenjem od 2 do $7 \%$ za kategoriju B,
- gubitak žarenjem od 4 do $9 \%$ za kategoriju C,

- maksimalni sadržaj hemijskih komponenata (hloridi max. $0,1 \%$; $\mathrm{SO}_{3}$ max. 3,0\%; slobodni $\mathrm{CaO} \max 2,5 \%$; reaktivni $\mathrm{CaO}$ max. $10 \%$ ),

- ukupan sadržaj oksida $\mathrm{SiO}_{2}+\mathrm{Al}_{2} \mathrm{O}_{3}+$ $\mathrm{Fe}_{2} \mathrm{O}_{3}$ min. $70 \%$,

- ukupan sadržaj alkalija max. 5\%.

\section{MINERALOŠKI I MORFOLOŠKI SASTAV LETEĆEG PEPELA}

Prema mineraloškom sastavu letećeg pepela moguće je izdvojiti tri vrste sastojaka, grupisanih kao neorganski, organski i fluidni deo (tabela 4) [19].

Na slici 3 prikazan je SEM izgled različitih čestica koje su prisutne u letećem pepelu.

Neorganski deo je predstavljen amorfnom (nekristalnom) i kristalnom fazom koja može biti magnetična i nemagnetična.

Amorfnu fazu čini staklasta amorfna masa koja se uglavnom sastoji od Al-Si jedinjenja $u$ različitim modifikacionim formama [20]. Maseni sadržaj ove faze u letećem pepelu zavisi od temperature sagorevanja uglja kao i brzine hlađenja pepela $\mathrm{i}$ može se kretati u rasponu od $66 \div 96 \%$. Staklasta, amorfna struktura je zapravo glavni nosilac pucolanskih osobina letećeg pepela [21].

Tabela 4. Morfološki sastav letećeg pepela [19]

\begin{tabular}{||l|l||}
\hline \multirow{4}{*}{\begin{tabular}{l||} 
NEORGANSKI \\
DEO
\end{tabular}} & $\begin{array}{l}\text { Nekristalne (amorfne) komponente } \\
\text { - Sferne i sferoidne čestice (guste, mehuraste, cenosfere, plerosfere, dermasfere, } \\
\text { ferosfere, itd). }\end{array}$ \\
\cline { 2 - 3 } & - Uglaste i nepravilne čestice (guste, šuplje, mehuraste, končaste, aglomerati itd). \\
\cline { 2 - 2 } & $\begin{array}{l}\text { Kristalne (mineralne) komponente } \\
\text { - Kristali i agregati }\end{array}$ \\
& - Zrna i grozdovi \\
& - Ferosfere i ferisfere \\
& - Skeletne sfere i sferoide \\
& - Aglomerati itd. \\
\hline
\end{tabular}




\begin{tabular}{|c|c|}
\hline \multirow{3}{*}{$\begin{array}{l}\text { ORGANSKI } \\
\text { DEO }\end{array}$} & $\begin{array}{l}\text { Ugljene komponente } \\
\text { - Slabo promenjene čestice uglja (guste, uglaste, nepravilne, okrugle, } \\
\text { hrapave, aglomerati itd.) }\end{array}$ \\
\hline & Polukoksne komponente \\
\hline & $\begin{array}{l}\text { Koksne komponente } \\
\text { - Sferne, sferoidne, uglaste i nepravilne čestice (guste, šuplje, mehuraste, } \\
\text { hrapave, skeletne, aglomerati, itd.). }\end{array}$ \\
\hline FLUIDNI DEO & $\begin{array}{l}\text { - Gasovito-tečne inkluzije u česticama nastale sagorevanjem organske i } \\
\text { neorganske materije iz uglja. }\end{array}$ \\
\hline
\end{tabular}

Morfološki gledano, amorfni deo letećeg pepela sastoji se iz sfernih i sferoidnih i nepravilnih čestica. Mikrosfere (sfere i sferoide) su rezultat laganog, delimičnog ili potpunog topljenja minerala uglja kao što su kvarc, glineni minerali, hloriti, liskun, feldspat i drugi minerali koji imaju nisku tačku topljenja. Zapreminski udeo sfera i sferoida $u$ pepelu varira $u$ opsegu od $10 \div 80 \%$, a učešće im raste sa porastom finoće pepela. Guste i mehuraste sfere, cenosfere i plerosfere su najčešći preds-tavnici, dok su dermasfere i ferosfere ređe prisutne. Veličina im se kreće u opsegu $1 \div 50 \mu \mathrm{m}$ [14].

Guste i mehuraste sfere (slika 3 a, c) potiču od kapljica rastopa različitih minerala iz kojih su potpuno (guste) ili delimično (mehuraste) isparile volatilni sastojci.

Cenosfere (slika 3 b, d, e) su šuplje sfere tankih zidova koje su ponekad izdeljene $\mathrm{u}$ sitne fragmente. Dimenzije im se obično kreću od $10 \div 250 \mu \mathrm{m}$ i generalno su veće od gustih i mehurastih sfera. Unutrašnjost sfere ispunjena je gasom iz okoline i gasom koji nastaje za vreme procesa sagorevanja kao posledica dekompozicije organske materije, karbonata, sulfida, sulfata, hidrosilikata i isparavanja higroskopne vlage iz uglja. Prisustvo i postojanost cenosfera može se objasniti visokom vrednošću viskoziteta otopljenog omotača i mogućnošću zadržavanja gasnih mehurova za vreme perioda očvršćavanja. Količina cenosfera u pepelu se kreće se između 15-20\% (vol).

Plerosfere (slika 3 f) su šuplje sfere ispunjene cenosferama malih dimenzija

Dermasfere (slika 3 g) su plerosfere koje imaju kristalni nukleus od mulita, hematita i drugih minerala i prekriveni su omotačem od alumosilikatnog stakla.

Ferosfere (slika 3 h, i, j) su sfere bogate gvožđem čija je osnovna struktura kristalne ili amorfne građe. Gvožđe u ferosferama je uglavnom prisutno $\mathrm{u}$ vidu ferispinela (kompleksan čvrst rastvor baziran na $\mathrm{Fe}_{3} \mathrm{O}_{4}$ sa primesama $\mathrm{Mg}, \mathrm{Mn}$ i Ca). Pri tom je unutašnja građa ferosfera određena morfologijom agregata ferispinela koji se nalaze u staklastoj fazi. Osim toga, u ferosferama mogu biti prisutni $\mathrm{i}$ hematit $\left(\alpha-\mathrm{Fe}_{2} \mathrm{O}_{3}\right)$, maghemit $\left(\gamma-\mathrm{Fe}_{2} \mathrm{O}_{3}\right)$, magnetit $\left(\mathrm{Fe}_{3} \mathrm{O}_{4}\right)$ trevorit $\left(\mathrm{NiFe}_{2} \mathrm{O}_{4}\right)$, ulvospinel $\left(\mathrm{TiFe}_{2} \mathrm{O}_{4}\right)$, jakobsit $\left(\mathrm{MnFe}_{2} \mathrm{O}_{4}\right)$ i mnogi drugi minerali, kao i bazna staklasta alumo-silikatna faza. [22, 23]. Najveći broj ferosfera ima skoro idealan sferni oblik. Ferosfere mogu biti šuplje i ispunjene, a prečnik im varira od nekoliko mikrona do čak $300 \mu \mathrm{m}$. [22]. 


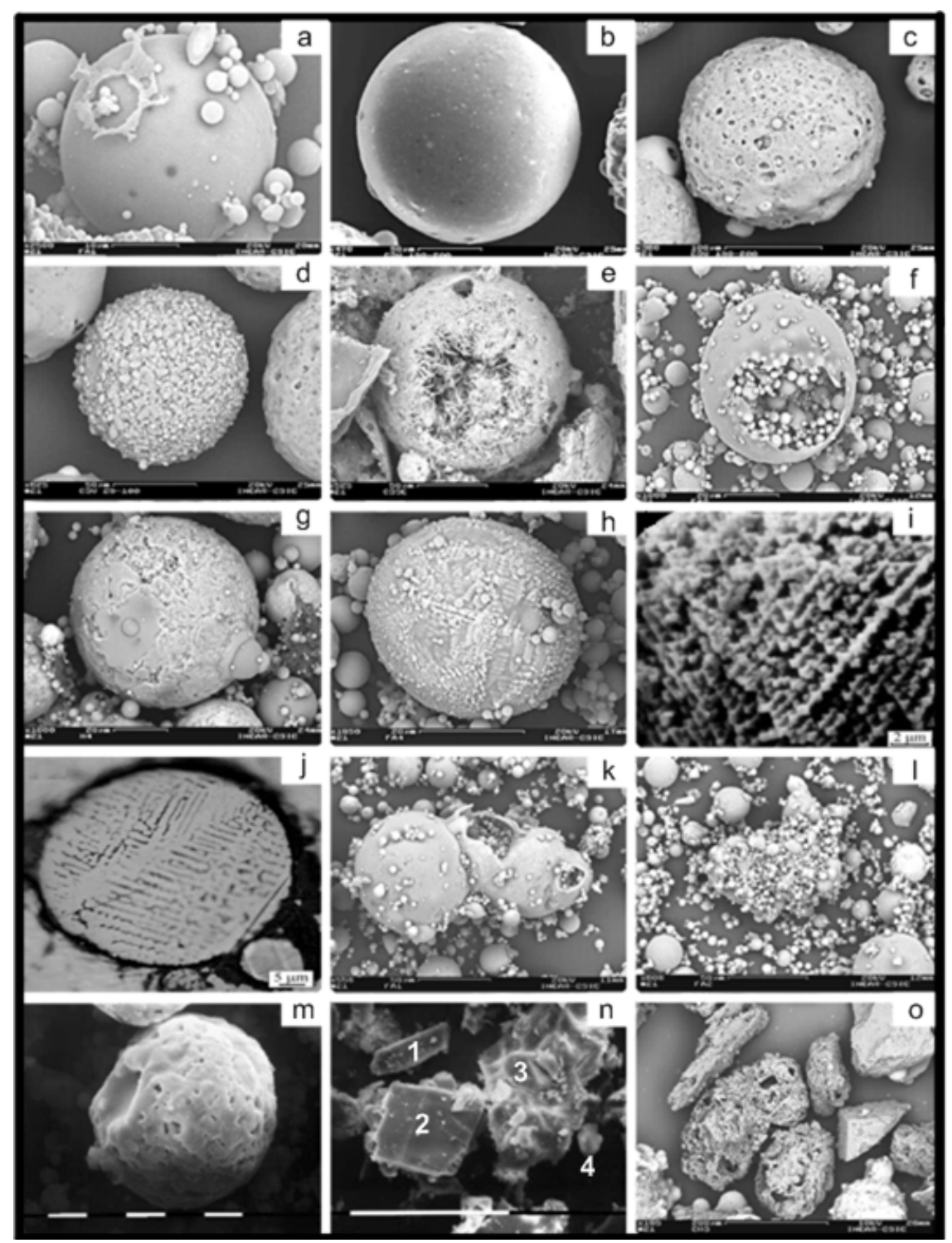

Sl. 3. SEM izgled čestica prisutnih u letećem pepelu:

$a$ - alumosilikatna staklasta sfera; $b$ - glatka alumosilikatna cenosfera; $c$ - mehurasta alumosilikatna cenosfera; $d$-alumosilikatna cenosfera sa kristalima kalcita i dolomita na površini; e - kristalna struktura mulit-kristobalit-kvarc u zidu alumosilikatne cenosfere;

$f$-alumosilikatna staklasta plerosfera, $g$ - dermasfera (larnit prekriven alumosilikatnim staklom); $h$-ferosfera sa dendritičnim kristalima magnetita u alumosilikatnom staklu; $i$ - površina ferosfere (orjentisani lanci ferospinela u staklastoj fazi); $j$ - unutrašnja struktura ferosfere; $k$-alumosilikatna staklasta sfera (desno) i porozni alumosilikatni sferoid (levo); l-staklasti aglomerat; m-plagioklasni sferoid; $n$ - gips (1), kalcit (2), kalcit prekriven Ca-Mg-Na-K fazom (3), opal (4); $o$ - različiti tipovi čestica organskog porekla [22, 5,6,12] 
Sferoide (slika $3 \mathrm{k}, \mathrm{m}$ ) se ne moraju značajno razlikovati od sfera, ali izgledaju poroznije i mehurastije. Veličina im se kreće u opsegu $10 \div 80 \mu \mathrm{m}$. Sferoide sadrže dve, tri ili više oblasti u kojima su raspoređeni gasni mehurovi [19].

Uglaste $i$ nepravilne čestice (slika 3 l) takođe nastaju topljenjem i hlađenjem mineralnih komponenata. Mogu biti kompaktne ili porozne, odnosno ispunjene mehurićima gasa. Često se javljaju u vidu grozdova nastalih usled grupisanja i aglomeracije čestica u plastičnoj fazi. Veličina im se kreće $60 \div 500 \mu \mathrm{m}$ [19].
Kristalnu fazu čine: kvarc, mulit, kristobalit, kalcit, anhidrit, kaolinit, feldspat kao i oksidi gvožđa (magnetit, maghemit, hematit). Pored navedenih minerala mogu se navesti i mnogi drugi koji se javljaju ređe ili u manjem obimu (slika $3 \mathrm{n}$; tabela 5).

Organski deo se sastoji od niza mineralnih neo-formacija od prvobitnog uglja do polukoksa i koksa (slika 3 o). Njihov sadržaj odgovara vrednosti gubitka žarenjem kod suvog uzorka letećeg pepela [14].

Fluidne materije čine vlaga, gasovi i gasovito-tečne inkluzije, koje su vezane za organski i neorganski deo.

Tabela 5. Mineraloški sastav kristalne komponente letećeg pepela [19]

\begin{tabular}{|c|l||}
\hline Silikati & $\begin{array}{l}\text { kvarc, kristobalit, kaolinit, mulit, andaluzit, plagioklas, kalijski feldspat, } \\
\text { olivin, piroksen, amfibol, cirkon, hlorit, liskun, vermikulit, talk, rankinit, } \\
\text { volastonit, larnit, melilit, montičelit, Ca-Mn silikati }\end{array}$ \\
\hline $\begin{array}{c}\text { Oksidi i } \\
\text { hidroksidi }\end{array}$ & $\begin{array}{l}\text { magnetit, maghemit, hematit, limonit, magnezioferit, ilmenit, spinel, } \\
\text { ferispinel, hromit, halkofanit, piroluzit, kuprit, tenorit, cinkit, rutil, anatas, } \\
\text { brokit, kreč, portlandit, periklas, brucit, korund, } \gamma \text { - } \mathrm{Al}_{2} \mathrm{O}_{3}, \mathrm{Al} \text { hidroksidi, } \\
\text { W-Nb-Pb oksidi }\end{array}$ \\
\hline Sulfati & gips, anhidrit, Fe sulfati, Mg sulfati, Na-K sulfati, barit \\
\hline Karbonati & kalcit, siderit, manganokalcit, dolomit, ceruzit, viterit \\
\hline Fosfati & apatit, svanbergit, vivianit, gojazit \\
\hline Sulfidi & pirhotin, pirit, Pb-Sb sulfidi, halkozin \\
\hline Ostali & staklo, organske materije, Fe karbid, grafit, šelit \\
\hline \hline
\end{tabular}

\section{ZAKLJUČAK}

Leteći pepeo je heterogena mešavina čestica različitih fizičkih, hemijskih, mineraloških i morfoloških osobina, koja nastaje sagorevanjem uglja u termoelektranama. Karakteristike letećeg pepela su prvenstveno određene kvalitetom izgorelog uglja, pre svega faznim sastavom neorganske komponente $\mathrm{u}$ uglju i njenim transformacijama $u$ toku sagorevanja. Pored toga, na kvalitet letećeg pepela utiče i tehnologija samog procesa sagorevanja.
Leteći pepeli su, najčešće, po svom hemijskom sastavu izrazito alumosilikatne materije, dok je prema mineraloškom sastavu moguće izdvojiti tri vrste sastojaka, grupisanih kao neorganski, organski i fluidni deo. Neorganski deo je predstavljen amorfnom i kristalnom fazom. Organski deo se sastoji od niza mineralnih neo-formacija od prvobitnog uglja do polukoksa i koksa, dok fluidne materije čine vlaga, gasovi i gasovito-tečne inkluzije vezane za čestice letećeg pepela. 


\section{LITERATURA}

[1] Fečko P., Kušnierovà M., Raclavskà H., Čablík V., Lyčkovà B: Fly ash, VŠB - Technical University of Ostrava (2005), p. 191

[2] Ilić I., Mogućnost primene mikroniziranog i klasiranog elektrofilterskog pepela kao aditiva za proizvodnju građevinskih materijala, magistarska teza, RGF Beograd (2009), str. 124

[3] Kostović M., Simović I., Kostović N, Bužalo A., Neki aspekti primene elektrofilterskog pepela u građevinarstvu, Zbornik radova: III Simpozijum "Reciklažne tehnologije i održivi razvoj", Sokobanja (2008), str. 97-103

[4] Okada T., Tomikawa H., Effects of chemical composition of fly ash on efficiency of metal separation in ashmelting of municipal solid waste, Waste Management, Volume 33, Issue 3 (2013), pp. 605-614

[5] Vassilev S.V., Menendez R., Alvarez D., Diaz-Somoano M., MartinezTarazona M.R., Phase-mineral and chemical composition of coal fly ashes as a basis for their multicomponent utilization. 1. Characterization of feed coals and fly ashes, Fuel, Vol. 82 (2003), pp. 1793-1811

[6] Vassilev S.V., Menendez R., DiazSomoano M., Martinez-Tarazona M.R., Phase-mineral and chemical composition of coal fly ashes as a basis for their multicomponent utilization. 2. Characterization of ceramic cenosphere and salt concentrates, Fuel, Vol. 83 (2004), pp. 585-603

[7] Vassilev S.V., Vassileva C. G., A new approach for the classification of coal fly ashes based on their origin, composition, properties, and behaviour, Fuel, Volume 86, Issues 10-11 (2007), pp. 1490-1512
[8] Temuujin J., Rickard W., Van Riessen A., Characterization of various fly ashes for preparation of geopolymers with advanced applications, Advanced Powder Technology, Volume 24, Issue 2 (2013), pp. 495-498

[9] Ural S., Comparison of fly ash properties from Afsin-Elbistan coal basin, Turkey, Journal of Hazardous Materials, Volume 119, Issues 1-3 (2005), pp. 85-92

[10] Sarkar A., Rano R., Udaybhanu G., Basu A. K., A comprehensive characterisation of fly ash from a thermal power plant in Eastern India, Fuel Processing Technology, Volume 87, Issue 3 (2006), pp. 259-277

[11] Vassilev S. V., Vassileva C.G., Geochemistry of coals, coal ashes and combustion wastes from coal-fired power stations, Fuel Processing Technology, Vol. 51, (1997), pp. 19-45

[12] Vassilev S. V., Vassileva C. G., Karayigit A. I., Bulut Y., Alastuey A., Querol X: Phase-mineral and chemical composition of composite samples from feed coals, bottom ashes and fly ashes at the Soma power station, Turkey, International Journal of Coal Geology, Vol. 61 (2005), pp. 35-63

[13] Standard ASTM C618

[14] Stefanović G., Fenomeni i mehanizmi u sistemu portland cement - leteći pepeo u zavisnosti od karakteristika letećeg pepela, Doktorska disertacija, Mašinski fakultet, Niš (2006)

[15] Das S. K., A simplified model for prediction of pozzolanic characteristics of fly ash, based on chemical composition, Cement and Concrete Research, Volume 36, Issue 10 (2006), pp. $1827-1832$ 
[16] Sharonova O. M., Solovyov L. A., Oreshkina N. A., Yumashev V. V., Anshits A. G., Composition of highcalcium fly ash middlings selectively sampled from ash collection facility and prospect of their utilization as component of cementing materials, Fuel Processing Technology, Volume 91, Issue 6 (2010), pp. 573-581

[17] Standard SRPS B.C1.018

[18] Standard EN 450-1

[19] Vassilev S. V., Vassileva C. G., Mineralogy of combustion wastes from coal-fired power stations, Fuel Processing Technology, Vol. 47 (1996), pp. 261-280

[20] Ward C.R., French D., Determination of glass content and estimation of glass composition in fly ash using quantitative X-ray diffractometry, Fuel, Volume 85, Issue 16 (2006), pp. 22682277
[21] Jovanović I., Bugarinović S., Obradović Lj., Mechanical characteristics of mortar containing fly ash treated by different physical methods (Mehaničke karakteristike maltera koji sadrži leteći pepeo tretiran različitim fizičkim postupcima), Rudarski radovi 4/2012 (2012), pp. 161-184

[22] Sokol E. V., Kalugin V. M., Nigmatulina E. N., Volkova N. I., Frenkel A.E., Maksimova N. V., Ferrospheres from fly ashes of Chelyabinsk coals: chemical composition, morphology and formation conditions, Fuel, Vol. 81 (2002), pp. 867-876

[23] Zhao Y., Zhang J., Sun J., Bai X., Zheng C., Mineralogy, chemical composition, and microstructure of ferrospheres in fly ashes from coal combustion, Energy Fuels, Vol 20 (2006), pp. 1490-1497 